Bangladesh J. Bot. 48(4): 1199-1206, 2019 (December)

\title{
MOLECULAR ANALYSIS OF YR GENES FOR YELLOW RUST RESISTANCE IN BREAD WHEAT (TRITICUM AESTIVUM L. EM THELL)
}

\author{
POOJA*, SS DHANDA AND NR YADAv ${ }^{1}$ \\ Department of Genetics and Plant Breeding, Chaudhary Charan Singh Haryana \\ Agricultural University, Hisar-125004 Haryana, India
}

Keywords: Recombinant inbred lines, SSR markers, $Y r$ genes, Grain yield

\begin{abstract}
Investigation was conducted to evaluate 210 recombinant inbred lines (RILs) of bread wheat to identify $Y r$ genes using SSR markers and response to stripe rust reaction. Recombinant inbred lines were screened under epiphytotic conditions and data in terms of per cent leaf area infected were recorded using Modified Cobb's Scale. A total of seven $Y r$ genes, namely Yr7, Yr18, Yr26, Yr29, Yr36, Yr47 and Yr53 were found to be linked to yellow rust resistance. Out of 40 Yr specific SSR markers, seven (Xgwm130 (Yr7), Xbarc 352 (Yr18), Xgwm 11 (Yr26), Xwmc 44 (Yr29), Xwmc 149 (Yr53), WKS1_I (Yr36) and Xcfb309 (Yr47) were found to be polymorphic in parental genotypes and RIL population indicating the presence or absence of $\mathrm{Yr}$ genes. Three RILs namely, 51, 52, 55 had largest number of resistant genes (4Yr genes) followed by six lines namely, RIL No. 20, 21, 23, 29, 39, 53 had 3 Yr genes having disease score (OS). These RILs may be utilized for incorporation of specific Yr genes in well adapted genotypes for improvement of disease resistance in bread wheat.
\end{abstract}

\section{Introduction}

Wheat is one of the important leading cereals providing daily sustenance to the large proportion of world. Since the initiation of the Green Revolution in the mid 60s, India achieved remarkable increase in production and productivity of wheat. India is the second largest producer of wheat in the world and wheat production had touched a record of $97.44 \mathrm{mt}$ from an area of $30.72 \mathrm{~m}$ ha during 2016-17 (Anon. 2017). It is one of the most significant food crops among cereals and serves as the staple food of about $36 \%$ of the entire world population (Talha et al. 2016). Increasing wheat yield potential in the developing world is a primary aim for food security concern (Duveiller et al. 2007). Both biotic and abiotic stresses are major hurdles for attaining this goal. Today, the most challenging task for wheat breeders is to increase grain yield as well as to improve the grain quality of crop (Goutam et al. 2013). Although wheat has a wide range of climatic adaptability, it is usually affected by many fungal diseases, the most devastating of which are the rust diseases.

All the three species of rusts, viz., stem (black) rust (Puccinia graminis Pers. f. sp. Tritici Eriks. \& E. Henn), leaf (brown) rust ( $P$. triticina Eriks.) and stripe (yellow) rust (P. striiformis Westend f. sp. tritici) infect wheat crop. Rust epidemics caused yield losses of more than one million tons in 1950, 1964, 1990 and 2002 (Wan et al. 2004, 2007). Stripe (yellow) rust is a widespread disease across major wheat growing regions with diverse cropping systems, growing seasons and germplasm characteristics (Wellings 2011). Losses from stripe rust have been estimated to be at least 5.5 million tons per year at worldwide level (Beddow et al. 2015). The $78 \mathrm{~S} 84$ and $46 \mathrm{~S} 119$ are the most prevalent pathotypes of yellow rust in north-western plain zone of India and identified virulent against $Y r 3, Y r 9$, and $Y r 27$ genes (Prashar et al. 2008). In 2001, India faced a major epidemic due to breakdown of $Y r 27$ and up to $70 \%$ losses were estimated (Prashar et al. 2007). During 2010-11, stripe rust appeared in severe form in the plains of Jammu and

*Author for correspondence: <deepooja16@gmail.com>. ${ }^{1}$ Department of Molecular biology, Biotechnology and Bioinformatics, Chaudhary Charan Singh Haryana Agricultural University, Hisar-125004 Haryana, India. 
Kashmir, foot hills of Punjab and Himachal Pradesh, parts of Haryana, and Tarai region of Uttarakhand (Sharma and Saharan 2011). Stripe rust continues to pose a threat to wheat cultivation worldwide (Sareen et al. 2012).

Stripe rust caused by the obligate biotroph fungus Puccinia striiformis, is a serious fungal disease for wheat, especially in cooler and moist environments (Chen et al. 2014). The temperature range for stripe rust infection is minimum of $0^{\circ} \mathrm{C}$, optimal of $11^{\circ} \mathrm{C}$ and maximum of $23^{\circ} \mathrm{C}$ (Curtis et al. 2002). The wheat cultivars become susceptible to rusts due to their narrow genetic base and the rapid rate of evolution of the pathogen, making it necessary to search for new source(s) of resistance. Till now, nearly 76 major genes conferring resistance to stripe rust ( $\mathrm{Yrl}$ to $\mathrm{Yr} 76$ ) have been identified (Dracatos et al. 2016, Xiang et al. 2016). Though remarkable progress has been made in breeding for stripe rust resistant varieties in India but the subsequent evolution of pathogenic races at much greater pace has challenged the breeding programmes (Khan and Saini 2009). Concerning co-evolution of plant and pathogen, the effectiveness of single gene to the resistance is limited and short-term. Use of diverse genes for providing resistance against stripe rust disease is the most economical and environmentally safe method. In view of these facts, $\mathbf{2 1 0}$ recombinant inbred lines of bread wheat were evaluated in this study for yellow rust resistance and molecular analysis of $\mathrm{Yr}$ genes. To identify genetically resistant and agronomically desirable genotypes for exploitation in a breeding programme aimed at improving grain yield potential of wheat.

\section{Materials and Methods}

The field experiment was conducted in the Research Area, Wheat and Barley Section, Department of Genetics and Plant Breeding, Chaudhary Charan Singh Haryana Agricultural University, Hisar, India located at $29^{\circ} 10^{\prime} \mathrm{N}$ latitude, $75^{\circ} 46^{\prime} \mathrm{E}$ longitude and altitude of $215.2 \mathrm{~m}$ above mean sea level. The present investigation was carried out on 210 RILs of bread wheat and two parents (WH542 as resistant parent and WH711 as susceptible parent) during Rabi season (November to April months) of 2015-16 and 2016-17. A mixture of stripe rust pathotypes 46S119, 47S103 and 78S84 was used to create epiphytotic conditions for screening parental genotypes and the RILs population obtained from Department of Plant Pathology, CCS Haryana Agricultural University, Hisar.

All the recombinant inbred lines of wheat including their parents were grown in $2 \mathrm{~m}$ paired rows, in 3 replications in randomized block design (RBD). Recommended package of practices were followed to raise the crop. The infector rows were grown after the interval of 10 entries as border rows of the experiment to ensure uniform infection. Data were recorded on the 5 plants/ replication/ RIL. Statistical analysis was done using OPSTAT software package (SPSS 1991).

Spray inoculums were done at tillering stage with urediospores of $P s t$ (conc. $\left.10^{6} / \mathrm{ml}\right)$. RILs were screened under epiphytotic conditions and data in terms of per cent leaf area infected were recorded using Modified Cobb's Scale (Peterson et al. 1948). Severity of disease was recorded in terms of per cent leaf area infection and pustule type was recorded as response.

A total of $40 \mathrm{Yr}$ specific SSR molecular markers were used for studying molecular polymorphism and to detect $\mathrm{Yr}$ genes among RILs population. Genomic DNA was isolated from the young leaves of wheat plants by using cetyl trimethyl ammonium bromide (CTAB) extraction method (Murray and Thompson 1980, Saghai-Maroof et al. 1984 and Xu et al. 1994). PCR amplified DNA fragments for DNA markers were resolved by submerged horizontal electrophoresis in $2.5 \%(\mathrm{w} / \mathrm{v})$ agarose gels. PCR amplified products were viewed under UV light fluorescence using photo UV transilluminator. The size (in nucleotides base pairs) of the amplified bands was determined based on its migration relative to standard DNA marker (100 bp DNA 
ladder). PCR reactions were standardized using known markers for $Y r$ genes. The presence of band run on agarose gel was taken as one and absence of band was read as zero in different lines and promising RILs were identified for $Y r$ genes.

\section{Results and Discussion}

From the Table 1 it is apparent that resistant parent (WH 542) showed zero per cent infection while the susceptible parent (WH 711) showed 60\% severity. Out of 210 RILs, 110 showed $0 \%$ infection, 46 RILs showed infection in traces, 10 RILs showed $0-5 \%, 6$ showed $5.1-10 \%, 9$ showed $10.1-15 \%, 6$ showed $15.1-20 \%, 6$ showed $20.1-30 \%, 14$ showed $30.1-40 \%$ and 4 showed $60 \%$ severity. All recombinant inbred lines were categorized into highly resistant (HR), moderately resistant (MR) and susceptible (S) on the basis of disease score for yellow rust.

Table 1. Disease score data for yellow rust.

\begin{tabular}{|c|c|c|}
\hline $\begin{array}{l}\text { Disease } \\
\text { score for } \\
\text { yellow rust }\end{array}$ & $\begin{array}{l}\text { Yellow } \\
\text { rust } \\
\text { reaction }\end{array}$ & RILs \\
\hline 0 & HR & $\begin{array}{l}\text { (110) WH542, 9,12,13,15,17, 18, 19, 20, 21, 22, 23, 24, 25, 27, 29, 31, 33, } \\
35,38,39,40,43,46,51,52,53,54,55,63,64,65,66,70,72,74,75,79, \\
80,83,90,91,92,98,100,104,108,111,112,113,114,115,116,117,118, \\
119,120,122,123,124,125,126,127,130,131,132,133,134,137,138, \\
139,140,141,142,145,146,147,148,149,150,152,153,154,163,169, \\
170,171,172,174,177,185,188,189,190,192,193,194,195,196,197, \\
199,200,201,202,203,204,205,206,208,209\end{array}$ \\
\hline $\mathrm{TS}$ & HR & $\begin{array}{l}\text { (46) } 3,6,7,11,16,26,28,30,32,34,36,41,47,48,50,57,62,67,69,71 \text {, } \\
73,76,77,78,81,84,85,86,87,89,93,95,97,106,107,109,128,144 \text {, } \\
159,160,162,165,166,175,176,179\end{array}$ \\
\hline $0-5 \mathrm{~S}$ & HR & (10) $180,184,187,191,207,10,37,135,158,198$ \\
\hline $5 S-10 S$ & MR & (6) $56,88,103,136,151,181$ \\
\hline $10 S-15 S$ & $\mathrm{~S}$ & (9) $5,44,49,59,96,102,105,161,167$ \\
\hline $15 S-20 S$ & $\mathrm{~S}$ & (6) $99,168,173,182,186,210$ \\
\hline $20-30 S$ & $\mathrm{~S}$ & (6) $4,60,94,101,129,183$ \\
\hline $30-40 \mathrm{~S}$ & $\mathrm{~S}$ & (14) $1,14,42,45,58,61,68,82,121,143,156,157,164,178$ \\
\hline $40-60 \mathrm{~S}$ & S & (5) WH711, 2, 8, 110, 155 \\
\hline
\end{tabular}

S - Susceptible, MS - Moderately susceptible, MR - Moderately resistance, R - Resistance.

Today, molecular markers are the best tools used to determine the level of genetic diversity among plants and can provide detailed characterization of genetic resources (Manifesto et al. 2001, Mir et al. 2012). The essential requirements for Marker Assisted Selection (MAS) in a plant breeding program is that markers should co-segregate with the desired trait, means to screen large populations and it should be available with high reproducibility across laboratories. Molecular marker aided selection methods resulted in significant improvement in breeding efficiency by reducing trial and error aspect of breeding process and also save time and cost. In the present study, 40 SSRs ( $Y r$ specific) were used for detecting polymorphism and to identify $Y r$ genes in 210 recombinant inbred lines of bread wheat. Out of these, $7 \mathrm{Yr}$ specific markers were polymorphic on parental genotypes. These were further screened in RIL population distinguishable on agarose gel electrophoresis. Seven $\mathrm{Yr}$ specific markers present on these parental genotypes include Xgwm130 ( $\mathrm{r} 7$ ), Xbarc 352 (Yr18), Xgwm 11 (Yr26), Xwmc 44 (Yr29), Xwmc 149 (Yr53), WKS1_I (Yr36), Xcfb309 
(Yr47). $Y r 7$ gene linked to $\mathrm{Xgwm} 130$ primer was observed in 26 RILs in present material (Table 2). Similarly, Yao et al. (2006) identified a microsatellite marker Xgwm 526 on the chromosome arm 2BL, linked closely with $Y r 7$ locus resistant to wheat stripe rust. $\operatorname{Yr} 18$ gene linked to Xbarc 352 primer was present in 16 RILs at molecular level, similar results were reported by Haque et al. (2014) that Xgwm 130 is linked to both of $L r 34 / Y r 18$ leaf and stripe rust resistance genes. $\operatorname{Yr} 26$ gene linked to Xgwm 11 primer was found to be present in $13 \mathrm{RILs}, \mathrm{Yr} 29$ gene was present

Table 2. $Y r$ genes present among recombinant inbred lines of bread wheat.

\begin{tabular}{|c|c|c|}
\hline Yr gene & RILs (210) & Recombinant inbred lines \\
\hline Xgwm130 (Yr7) & 26 RILs & $\begin{array}{l}3,7,9,18,19,20,21,23,29,30,31,35,39,46,51,52,66,70,76,79,82, \\
117,121,170,171,190\end{array}$ \\
\hline Xbarc $352($ Yr18) & 16 RILs & $21,22,23,24,25,32,33,67,73,103,107,110,112,113,120,123$ \\
\hline Xgwm $11($ Yr26) & 13 RILs & $3,6,12,15,23,24,39,40,43,51,55,93,128$ \\
\hline Xwmc44 (Yr29) & 17 RILs & $12,13,15,18,19,20,45,63,64,85,115,124,126,133,134,135,140$ \\
\hline Xwmc $149($ Yr53) & 17 RILs & $51,52,53,55,62,63,65,75,180,183,191,195,196,198,201,207,208$ \\
\hline WKS1_I (Yr36) & 19 RILs & $25,27,29,39,40,51,52,53,55,56,64,67,72,73,74,114,118,119,141$ \\
\hline Xcfb309 (Yr47) & 32 RILs & $\begin{array}{l}7,8,10,17,20,21,26,27,28,29,38,46,48,52,53,54,55,66,71,74 \\
82,89,91,92,93,94,115,117,121,124,133,135\end{array}$ \\
\hline
\end{tabular}

in 17 RILs at molecular level linked to primer Xwmc 44. This indicated the presence of stripe rust resistance against $Y r 26$ and $Y r 29$ genes in the present set of material. Parveen et al. (2014) showed the presence of $Y_{r 29}$ using Xwmc 44 PCR based DNA markers as reported by Suenaga et al. (2001) and Yr26/Yr15 using Xgwm11 reported by Ali et al. (2010) in the advanced wheat lines. Yr53 gene was present in 17 RILs at molecular level linked to primer Xwmc 149, Yr36 gene linked to WKS1_I primer was found to be located in 19 RILs. Fu et al. (2009) also confirmed the identity between WKS1 and Yr36 and transformed the susceptible wheat variety 'Bobwhite' with a 12.2-kb genomic fragment that includes the complete WKSI coding and flanking regions. Thirty two recombinant inbred lines showed the presence of Yr47 linked to Xcfb309 primer. Similarly, Bansal et al. (2011) also characterized the combination of flanking markers gwm 234 and Xcfb309 to ascertain the presence of $\mathrm{Lr} 52$ and $\mathrm{Yr} 4 \mathrm{~T}$ in segregating populations and characterized a valuable source of dual leaf rust and stripe rust resistance for deployment in new wheat cultivars AUS28183 and AUS28187. Xu et al. (2012) determined the location of Yr53 on 2BL, using Xwmc149 as one of the SSR marker along with Xbarc349, Xwmc501, Xwmc441 indicating that the resistance gene is on the chromosome near the centromere of $2 \mathrm{BL}$ in durum wheat accession PI 480148

Among these RILs, the RIL No. 4 was susceptible to yellow rust (30S), while the RIL No. 9 and 135 showed resistant reactions ( 0 - Ts) and confirmed by $Y r 7, Y r 29$ and $Y r 47$ genes. This was followed by another group of 7 lines, namely RIL No. 5, 10, 12, 28, 32, 70, and 123 performed significantly better for grain yield. These lines also indicated resistant reaction to yellow rust ( 0 5S) as validated by the presence of $Y r 7, Y r 18, Y r 26, Y r 29, Y r 47$ genes. Another group of ten RILs mainly, RIL No. 1, 2, 3, 35, 36, 71, 93, 120, 127, and 139 also performed significantly better than their corresponding mean values for grain yield. Out of these lines, RIL No. 2 showed susceptible reaction (60S) score to yellow rust while other lines showed resistant reaction $(0-\mathrm{Ts})$ for yellow rust as indicated by the presence of $Y r 7, Y r 18, Y r 26, Y r 47$ genes. With regard to disease resistance, three RILs namely, 51, 52, 55 had largest number of resistant genes ( $4 \mathrm{Yr}$ genes) with resistance score (0S) followed by six lines namely, RIL No. 20, 21, 23, 29, 39, 53 had 3 Yr genes with resistance score (OS) (Table 3). These RILs may be utilized for incorporation of present Yr genes in well adapted 
genotypes for improvement of disease resistance in bread wheat. Ali et al. (2010) screened 35 SSR primer pairs on the parents and on $\mathrm{F}_{2}$ population, the result indicated that most of the resistant plants amplified same band as resistant parent while susceptible plants amplified same as susceptible parents. Ullah et al. (2016) reported that, out of 99 experimental lines, S19M93 and S23M41 markers revealed the presence of $Y r 5$ gene in 86 and 70 genotypes, respectively. While, Xpsp3000 suggested presence of $Y r 10$ gene in 66 genotypes in spring bread wheat lines. Mukhtar et al. (2015) reported Xpsp3000 has band size of $260 \mathrm{bp}$ and characterized wheat germplasm for stripe rust resistance. This will facilitate gene pyramiding approaches against stripe rust and may be useful in future wheat improvement programs. Xu et al. (2014) validated 8 SSR and 6 STS

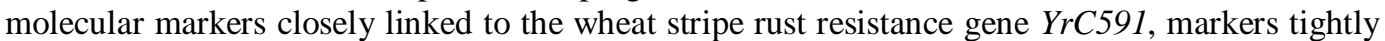
linked to $\operatorname{YrC591}$ proved useful for tracing gene in wheat MAS breeding programs. Therefore, more resistance genes and QTL should be identified for agricultural use. It is important to develop diagnostic markers for marker-assisted selection (MAS) in order to ensure resistance diversity.

Table 3. Recombinant inbred lines of bread wheat identified with $\mathrm{Yr}$ genes.

\begin{tabular}{cl}
\hline $\begin{array}{c}\text { Total number of } \\
\text { RILs }\end{array}$ & 210 \\
\hline With $1 Y r$ gene & $\mathbf{6 0}(6,8,9,10,13,17,22,26,28,30,31,32,33,35,38,43,45,48,54,56,62$, \\
& $65,70,71,72,75,76,79,85,89,91,92,94,103,107,110,112,113,114,118$, \\
& $119,120,123,126,128,134,140,141,170,171,180,183,190,191,195,196$, \\
& $198,201,207,208)$ \\
With $2 Y r$ gene & $\mathbf{2 5}(3,7,12,15,18,19,24,25,27,40,46,63,64,66,67,73,74,82,93,115,117$, \\
& $121,124,133,135)$ \\
With $3 Y r$ gene & $\mathbf{6}(20,21,23,29,39,53)$ \\
With $4 Y r$ gene & $\mathbf{3}(51,52,55)$ \\
\hline
\end{tabular}

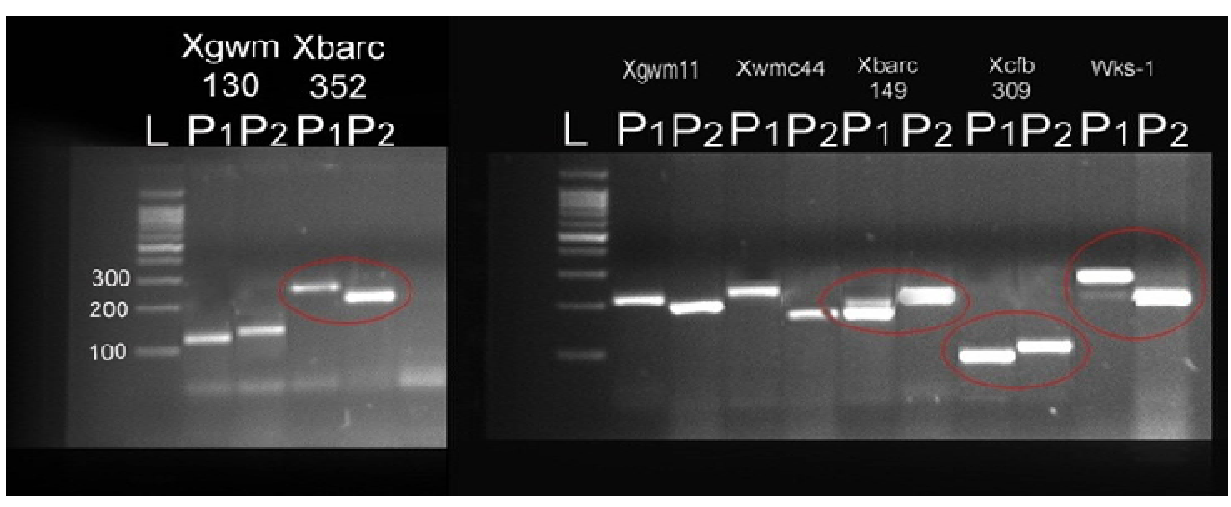

L - 100bp ladder, $\mathrm{P}_{1}$ - Parent WH542, $\mathrm{P}_{2}$ - Parent WH 711

Fig. 1. Parental polymorphism for seven $\mathrm{Yr}$ specific SSR markers.

A total of seven $Y r$ genes, namelyYr7, $Y r 18, Y r 26, Y r 29, Y r 36, Y r 47$ and $Y r 53$ were found linked to yellow rust resistance. $\operatorname{Yr} 26$ and $\operatorname{Yr} 36$ were found effective with disease resistance $(0$ Ts) in the present set of material. Three RILs namely, 51, 52, 55 had largest number of resistant genes ( $4 \mathrm{Yr}$ genes) followed by six lines namely, RIL No. 20, 21, 23, 29, 39, 53 which had $3 Y r$ genes having disease score (OS). These RILs may be utilized for incorporation of present Yr genes in well adapted genotypes for improvement of disease resistance in bread wheat. The present study identified the lines that may be further utilized for improvement of yellow rust resistance in bread 
wheat and further will help the researchers to uncover the critical areas of how to tackle this damaging disease instead of using fungicides that is contaminating the food chain.
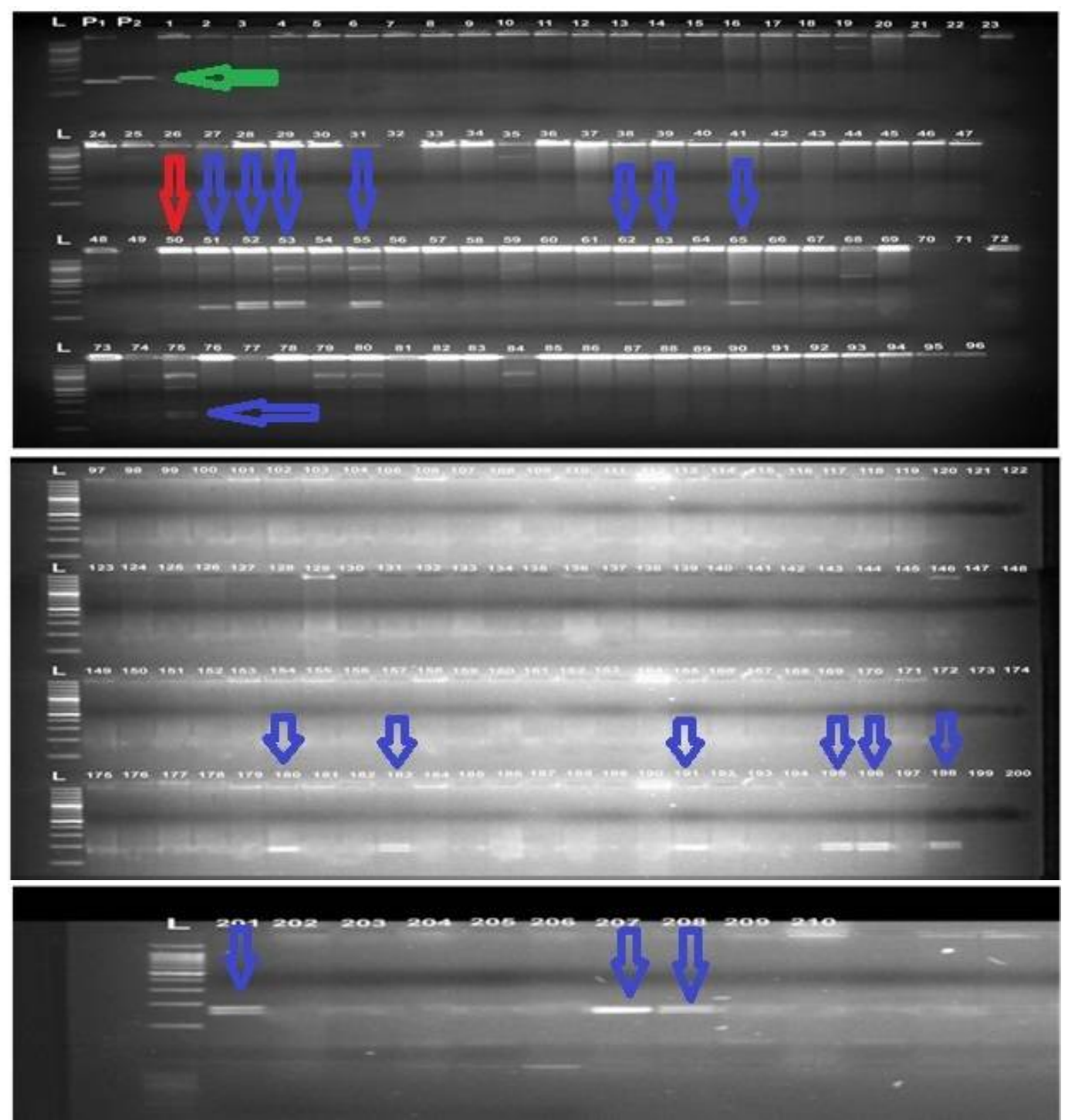

L - 100bp ladder, $\mathrm{P}_{1}$ - Parent WH542, $\mathrm{P}_{2}$ - parent WH 711. Red arrow - absence of band in line no. 50 , blue - presence of band in line no. 51, green- band at different bp.

Fig. 2. Allelic polymorphism among WH542, WH711 and RILs for Xwmc149 (Yr53).

\section{References}

Ali M, Ji WQ, Hu YG, Baloch GM, Zhong H and Wang CY 2010. Molecular implications from SSR markers for stripe rust (Puccinia striiformis f. sp. tritici) resistance gene in bread wheat line $\mathrm{n} 95175$. Pak. J. Bot. 42: 383-390. 
Anonymous 2017. Progress Report of the All India Co-ordinated Wheat and Barley Improvement Project. Crop Improv. 01. ICAR-Indian institute of Wheat and Barley Research, Karnal, India.

Bansal UK, Forrest KL, Hayden MJ, Miah H, Singh D and Bariana HS 2011. Characterization of a new stripe rust resistance gene $\mathrm{Yr} 47$ and its genetic association with the leaf rust resistance gene $\operatorname{Lr} 52$. Theor. Appl. Genet. 122(8): 1461-1466.

Beddow JM, Pardey PG, Chai Y, Hurley TM, Kriticos DJ and Braun JC 2015. Research investment implications of shifts in the global geography of wheat stripe rust. Nat. Plants 1: 132.

Chen W, Wellings C, Chen X, Kang Z and Liu T 2014. Wheat stripe (yellow) rust caused by Puccinia striiformis f. sp. tritici. Mol. Pl. Patho. 15: 433-446.

Curtis BC, Rajaram S and Macpherson HG 2002. In Bread wheat improvement and production Number 30. Food and Agriculture Organization of the United Nations, Rome Italy. 554.

Dracatos PM, Zhang P, Robert F, Park RF, McIntosh RA and Wellings CR 2016. Complementary resistance genes in wheat selection 'Avocet R' confer resistance to stripe rust. Theor. Appl. Genet. 129: 65-76.

Duveiller E, Singh RP and Nicol JM 2007. The challenges of maintaining wheat productivity: Pests, diseases and potential epidemics. Euphytica. 157: 417-443.

Fu DL, Cristobal U, Assaf D, Ann B, Lynn E, Chen X M 2009. A Kinase-START gene confers temperature dependent resistance to wheat stripe rust. Science 323: 1357-1360.

Goutam U, Kukreja S, Tiwari R, Chaudhary A, Gupta RK and Dholakia BB 2013. Biotechnological approaches for grain quality improvement in wheat: present status and future possibilities. Aust. J. Cereal Sci. 7: 469-483.

Haque A, Shaheen T, Gulzar T, Rahman MU, Jalal F, Sattar S, Ehsan B, Iqbal Z and Younas M 2014. Study of rust resistance genes in wheat germplasm with DNA markers. Bioinformation 10(6): 371-377.

Khan MA, Kamaluddin and Saini RG 2009. Chromosomal location of non-hypersensitive leaf rust resistance genes in bread wheat cultivar PBW65 using microsatellite markers. Ind. J. Biotechnol. 11: 412-415.

Manifesto MM, Schlatter AR, Hopp HE, Suarez EY and Dubcovsky J 2001. Quantitative evaluation of genetic diversity in wheat germplasm using molecular markers. Crop Sci. 41: 682-690.

Mir R, Kumar D and Balyan 2012. A study of genetic diversity among Indian bread wheat (Triticum aestivum L.) cultivars released during last 100 years. Genet. Reso. \& Crop Evol. 59(5): 717-726.

Mukhtar S, Khan MA, Paddar BA, Anjum A, Zaffar G, Mir SA, Naseer S, Bhat MA and Kamaluddin 2015. Molecular characterization of wheat germplasm for stripe rust resistance genes ( $Y r 5, \operatorname{Yr} 10, \operatorname{Yr} 15$ and Yr18) and identification of candidate lines for stripe rust breeding in Kashmir. Ind. J. of Biotech. 14: 241-248.

Murray MG and Thompson WF 1980. Rapid isolation of high molecular weight plant DNA. Nucleic Acid Resources. 8: 4321-4325.

Parveen Z, Iqbal N, Rahman SU, Younis M, Nawaz M, Raza SH and Iqbal MZ 2014. Rust resistance evaluation of advanced wheat (Triticum aestivum L.) genotypes using PCR-based DNA markers. Pak. J. Bot. 46(1): 251-257.

Peterson RF, Campbell AB and Hannah AE 1948. A diagrammatic scale for estimating rust intensity on leaves and stems of cereals. Can. J. Res. 26(5): 496-500.

Prashar M, Bhardwaj SC, Jain SK and Datta D 2007. Pathotypic evolution in Puccinia striiformis in India during 1995-2004. Aust. J. Agri. Res. 58: 602-604.

Prashar M, Bhardwaj SC, Jain SK, Sharma YP and Mishra B 2008. Perspective on wheat rusts in India. In: 11th International Wheat Genetics Symposium. Sydney, Australia, (http://hdl.handle.net/ 2123/3329).

Saghai-Maroof MA, Soliman KM, Jorgensen RA and Allard RW 1984. Ribosomal DNA spacer-length polymorphism in Barley: Mendelian inheritance, Chromosomal-location and population dynamics. Proced.of Nat. Acad. and Sci. U.S.A. 81: 8014-8019.

Sareen P, Sundeep K, Uttam K, Lakshman P and Amit KS 2012. Pathological and molecular characterizations of slow leaf rusting in fifteen wheat (Triticum aestivum L.) genotypes. Afri. J. of Biotechnol. 11: 14956-14966.

Sharma I and Saharan MS 2011. Status of wheat diseases in India with a special reference to stripe rust. Plant Dis. Res. 26: 0970-4914.

SPSS Inc. 1991. Statistical algorithms. Chicago: SPSS, Inc.. 
Suenaga K, Singh RP, Huerta-Espino J and William HM 2003. Microsatellite markers for genes Lr34/Yr18 and other quantitative trait loci for leaf rust and stripe rust resistance in bread wheat. Phytopath. 93: 881-890.

Talha M, Swati, Harsha and Jaiswal JP 2016. Marker assisted detection of underutilized potential $\operatorname{Yr}$ genes in elite wheat breeding lines. SABRAO J. Breed. and Genet. 48 (3): 309-317.

Ullah N, Niaz Ali, Iqbal M, Aziz-ud-Din, Shah AH, Rahman IU, Ahmad H, Inamullah, Ali GM 2016. Markers assisted selection for multiple stripe rust resistance genes in spring bread wheat lines. Int. J. Biosci. 8(3): 63-74.

Wan AM, Chen XM and He ZH 2007. Wheat stripe rust in China. Aust. J. of Agri. Res. 58: 605-619.

Wan AM, Zhao ZH, Chen XM, He ZH and Jin SL 2004. Wheat stripe rust epidemic and virulence of Puccinia striiformis f. sp. Tritici in China in 2002. Plant Disease 88: 896-904.

Wellings CR 2011. Global status of stripe rust: a review of historical and current threats. Euphytica 179: 129-141.

Xiang C, Feng J, Wang M, Chen X, See DR, Wan A and Wang T 2016. Molecular mapping of stripe rust resistance gene Yr76 in winter club wheat cultivar Tyee. Phytopathology 106: 1186-1193.

Xu H, Zhang J, Zhang P, Qie, Niu Y, Li H, Ma P, Xu Y and An D 2014. Development and validation of molecular markers closely linked to the wheat stripe rust resistance gene $\operatorname{YrC591}$ for marker-assisted selection. Euphytica 198: 317-323.

Xu X, Liu X, Ge S, Jensen JD, Hu F and Li X 2012. Resequencing 50 accessions of cultivated and wild rice yields markers for identifying agronomically important genes. Nat. Biotechnol. 30:105-111.

Xu Y, Shimoro X and Hofstra H 1994. Plant DNA isolation protocol. Nucleic Acid Res. 22: 2399-2403.

Yao ZJ, Lin RM and Xu SC 2006. Inheritance analysis of wheat yellow rust resistance of the international differential host Lee to Chinese isolates CY23. Pl. Protection 32: 41-43.

(M anuscript received on 29 October, 2018; revised on 12 February, 2019) 